\title{
Disturbances of haemostasis in diabetes mellitus
}

\author{
Mohamed A. Fattah ${ }^{\mathrm{a}}$, Mohamed H. Shaheen ${ }^{\mathrm{b}}$ and M. Hesham Mahfouz ${ }^{\mathrm{c}, *}$ \\ ${ }^{a}$ Department of Biochemistry, Faculty of Science, Ain Shams University. Cairo, Egypt \\ ${ }^{\mathrm{b}}$ Department of Clinical Pathology, Military Medical Academy, Cairo, Egypt \\ ${ }^{\mathrm{c}}$ Department of Biochemistry, National Institute of Diabetes and Endocrinology, Cairo, Egypt
}

\begin{abstract}
Diabetes mellitus is associated with disturbances in haemostasis that could contribute to the development of thrombotic complications. The present study was undertaken to determine the behavior of coagulation variables and fibrinolytic system in diabetes mellitus. Forty five diabetic patients and forty five matched controls were evaluated by doing the following haemostatic parameter, prothrombin time, partial thromboplastin time, thrombin time, coagulation factors assay II, VII, IX, \& plasma fibrinogen, ADP-induced platelet aggregation, protein C, $a_{2}$ - antiplasmin, PAI and FDPs. Generally diabetic patients have high levels of fibrinogen, $a_{2}$ - antiplasmin, \& PAI and lower level of protein C. Other haemostatic parameters did not show statistically significant difference between diabetic patients and control group. Significantally elevated levels of PAI, $a_{2}$ - antiplasmin together with low protein $\mathrm{C}$ level in diabetic patients may result in the disturbance of haemostatic balance favoring thrombotic events. Conclusion: High levels of plasma fibrinogen, $a_{2} \mathrm{~A}$ - antiplasmin with low plasma protein $\mathrm{C}$ activity could lead to a prothrombotic tendency in insulin dependent diabetic patients. Moreover, in non-insulin dependent diabetic patients, the above mentioned parameters together with high levels of ADP-induced platelet aggregation and plasminogen activator inhibitor may increase the risk of thrombotic complications. Obesity can be considered as an additional risk factor for development of thrombosis in diabetic patients.
\end{abstract}

Keywords: Diabetes mellitus, haemostatic disturbances, coagulation factors, fibrinolytic system

\section{Introduction}

Diabetes mellitus is one of the most common serious metabolic disorders in man. It is not one, but rather a group of related diseases characterized by chronic hyperglycemia [3].

The fibrinolytic system is natural defense against thrombosis. A balance exists between plasminogen activators and inhibitors, and impairment of this balance can caused either by diminished release of tissue plasminogen activator (t-PA) or increased levels of plasminogen activator inhibitor 1 (PAI-1). PAI-1 is a serine protease inhibitor and evidence suggests that

${ }^{*}$ Corresponding author: Dr. M. Hesham Mahfouz, Faculty of Medicine \& Medical Sciences, Biochemistry Department, Umm AlQura University, P.O. Box 7607, Makkah, Saudi Arabia. E-mail: mhesham5@yahoo.com. it is the major regulator of the fibrinolytic system. It binds and rapidly inhibits from an inactive irreversible complex [5].

Diabetes mellitus associated with both metabolic and vascular abnormalities and although a causal link between the two has been suggested. This has not been fully established [13]. Patients with diabetes mellitus have an increased risk of cardiovascular diseases, especially myocardial infarction, cerebrovascular and peripheral vascular diseases. These complications account for $80 \%$ of the deaths in people with non-insulin dependent diabetes. With $60 \%$ attributable to ischemic heart disease. Much attention has been devoted to the pathogenic factors, altered haemostatic balance, including abnormalities in platelet function, increase in blood coagulability and altered fibrinolytic system [17]. Since most of these abnormalities indicate a hypercoagulable and hypofibrinolytic state leading to enhance 
Table 1

Haemostasis parameters of insulin dependent diabetic patients compared to healthy control group

\begin{tabular}{|c|c|c|c|c|c|c|c|}
\hline Groups & $\begin{array}{l}\text { Prothrombin } \\
\text { Time (PT) } \\
(\text { secs })\end{array}$ & $\begin{array}{c}\text { Partial } \\
\text { Thromboplastin } \\
\text { Time (PTT) (Secs) }\end{array}$ & $\begin{array}{c}\text { Thrombin } \\
\text { Time (TT) } \\
\text { (Secs) }\end{array}$ & $\begin{array}{c}\text { Plasminogen } \\
(\%)\end{array}$ & $\begin{array}{c}a_{2^{-}} \\
\text {antiplasmin } \\
(\%)\end{array}$ & $\begin{array}{c}\text { Plasminogen } \\
\text { activator inhibitor } \\
(\mathrm{IU} / \mathrm{ml})\end{array}$ & $\begin{array}{c}\text { Fibrin } \\
\text { degradation } \\
\text { products (FDPs) }\end{array}$ \\
\hline \multicolumn{8}{|l|}{ Healthy controls } \\
\hline Range & $(11.4-15.0)$ & $(30.5-39.1)$ & $(13.5-17.2)$ & $(77.0-133.0)$ & $(79.0-145.0)$ & $(0.3-2.8)$ & Negative \\
\hline Mean \pm S.E. & $12.85 \pm 0.29$ & $35.48 \pm 0.63$ & $15.15 \pm 0.31$ & $106.0 \pm 3.75$ & $103.1 \pm 4.5$ & $1.853 \pm 0.192$ & \\
\hline $\begin{array}{l}\text { Insulin dependent } \\
\text { diabetic patients } \\
\text { (IDDM): }\end{array}$ & & & & & & & \\
\hline Range & $(11.4-14.0)$ & $(28.0-45.0)$ & $(12.4-18.5)$ & $(66.09-122.4)$ & $(105-185)$ & $(0.51-3.56)$ & Negative \\
\hline Mean \pm S.E. & $12.31 \pm 0.22$ & $36.87 \pm 1.3$ & $15.8 \pm 0.47$ & $104.01 \pm 3.824$ & $143.2 \pm 6.5$ & $2.161 \pm 0.253$ & \\
\hline $\mathrm{P}$ value $=$ & N.S. & N.S. & N.S. & N.S. & 0.001 & N.S. & \\
\hline
\end{tabular}

$P$ value: t-test for distribution differences between two samples means.

N.S.: Non-significant.

$p=0.001$ : Very highly significant.

Table 2

Fibrinogen, factors II, VII, IX \& X, protein C and ADP-induced platelet aggregation levels in insulin dependent diabetic patients compared to healthy control group

\begin{tabular}{|c|c|c|c|c|c|c|c|}
\hline Groups & $\begin{array}{c}\text { Fibrinogen } \\
(\mathrm{mg} / \mathrm{dl})\end{array}$ & $\begin{array}{l}\text { Factor } \\
\text { II }(\%)\end{array}$ & $\begin{array}{c}\text { Factor } \\
\text { VII }(\%)\end{array}$ & $\begin{array}{l}\text { Factor } \\
\text { IX (\%) }\end{array}$ & $\begin{array}{l}\text { Factor } \\
\mathrm{X}(\%)\end{array}$ & $\begin{array}{l}\text { Protein } \\
\mathrm{C}(\%)\end{array}$ & $\begin{array}{c}\text { ADP-induced } \\
\text { platelet } \\
\text { aggregation }(\%)\end{array}$ \\
\hline \multicolumn{8}{|l|}{ Healthy controls } \\
\hline Range & $(210-355)$ & $(78-157)$ & $(82-148)$ & $(75-145)$ & $(78-160)$ & (79-160) & $(55-90)$ \\
\hline Mean \pm S.E. & $279.8 \pm 11.3$ & $113 \pm 6.5$ & $108.3 \pm 5.0$ & $108 \pm 5.9$ & $115.8 \pm 5.4$ & $121.6 \pm 6.3$ & $68 \pm 2.91$ \\
\hline \multicolumn{8}{|l|}{ Insulin Dependent } \\
\hline \multicolumn{8}{|c|}{ Diabetic Patients (IDDM): } \\
\hline Range & $(220-215)$ & $(70-135)$ & $(65-145)$ & $(75-170)$ & $(75-150)$ & $(20-120)$ & $(58-85.2)$ \\
\hline Mean \pm S.E. & $339.7 \pm 19.9$ & $103.3 \pm 5.2$ & $94.7 \pm 6.4$ & $107 \pm 6.7$ & $106 \pm 5.7$ & $68.3 \pm 8.2$ & $72.12 \pm 2.35$ \\
\hline $\mathrm{P}$ value $=$ & 0.05 & N.S. & N.S. & N.S. & N.S. & 0.001 & N.S. \\
\hline
\end{tabular}

$P$ value: t-test for distribution differences between two samples means..

N.S.: Non-significant.

$p=0.05$ : Significant.

$p=0.001$ : Very highly significant.

intravascular fibrin deposition, they have been linked to the high risk for cardiovascular morbidity and mortality among these patients [25].

The aim of this study was undertaken to determine the behavior of haemostatic variables and also the risk factors associated with diabetes mellitus.

\section{Patients and methodes}

The present study has been carried out on diabetic outpatients clinic of Maadi Armed Forces Hospital, Cairo. The study was conducted on 90 cases (45diabetic patients and 45 healthy controls of matched age and sex as the diabetic patients). The diabetic patients were stratified according to WHO criteria (1985) as follows:

- Group I: Comprised fifteen insulin-dependent diabetic patients (aged 12-21 years).
- Group II: Comprised fifteen non-obese, noninsulin dependent diabetic patients (aged 4164 years), their body mass index below $30 \mathrm{~kg} / \mathrm{m}^{2}$.

- Group III: Comprised fifteen obese, non-insulin dependent diabetic patients (aged 43-58 years), their body mass index above $30 \mathrm{~kg} / \mathrm{m}^{2}$.

Controls were divided into three groups:

- Group a: Comprised fifteen healthy volunteers of matched age and sex as group I of insulin dependent diabetic patients.

- Group b: Comprised fifteen healthy non-obese adult control, age ranges from 43 to 65 years with matched sex as group II.

- Group c: Comprised fifteen obese adult control, age ranges from 42 to 59 years with matched sex as group III.

Plasma from controls and diabetic patients were subjected to the following assessments: prothrombin time, 
Table 3

Haemostasis parameters of non-insulin dependent diabetic patients compared to non-obese healthy control group

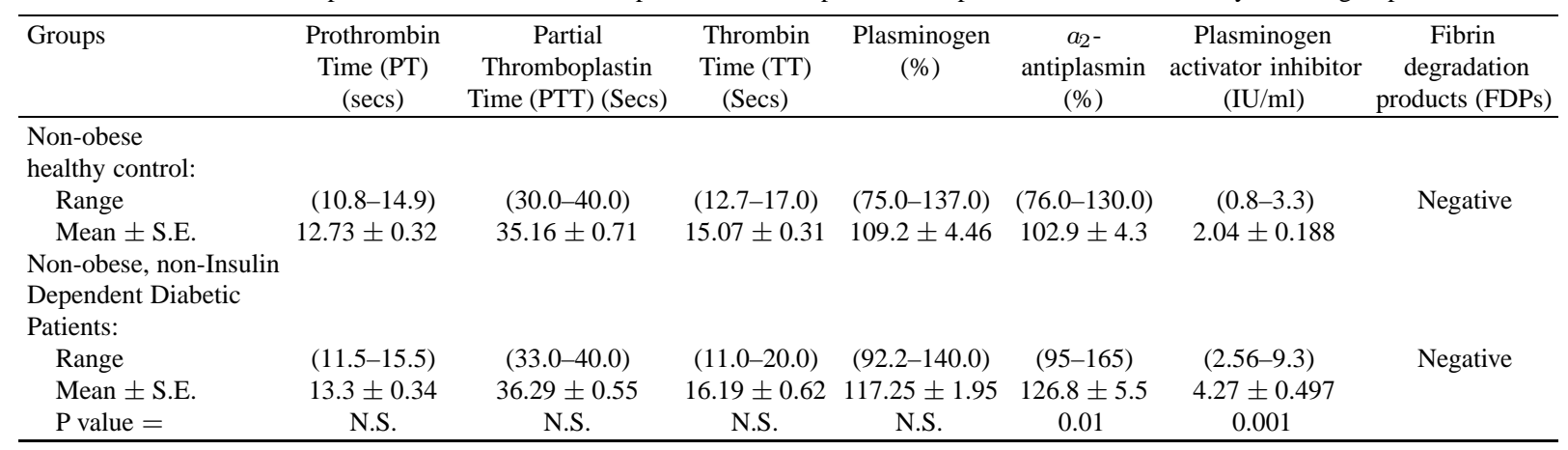

P value: $t$-test for distribution differences between two samples means.

N.S.: Non-significant.

$p=0.01$ : Highly significant.

$p=0.001$ : Very highly significant.

Table 4

Fibrinogen, factors II, VII, IX \& X, protein C and ADP-induced platelet aggregation levels in non- obese, non- insulin dependent diabetic patients compared to non-obese healthy control group

\begin{tabular}{|c|c|c|c|c|c|c|c|}
\hline Groups & $\begin{array}{c}\text { Fibrinogen } \\
(\mathrm{mg} / \mathrm{dl})\end{array}$ & $\begin{array}{l}\text { Factor } \\
\text { II }(\%)\end{array}$ & $\begin{array}{c}\text { Factor } \\
\text { VII }(\%)\end{array}$ & $\begin{array}{c}\text { Factor } \\
\text { IX }(\%)\end{array}$ & $\begin{array}{l}\text { Factor } \\
\mathrm{X}(\%)\end{array}$ & $\begin{array}{l}\text { Protein } \\
\text { C }(\%)\end{array}$ & $\begin{array}{c}\text { ADP-induced } \\
\text { platelet } \\
\text { aggregation }(\%)\end{array}$ \\
\hline \multicolumn{8}{|c|}{ Non-obese healthy control: } \\
\hline Range & $(210-358)$ & $(78-150)$ & $(77-150)$ & $(77-160)$ & $(72-145)$ & $(85-145)$ & $(52-81)$ \\
\hline Mean \pm S.E. & $269.7 \pm 10.5$ & $111.9 \pm 6.0$ & $107.4 \pm 5.3$ & $113.5 \pm 6.6$ & $113.3 \pm 5.3$ & $113.6 \pm 4.4$ & $65.13 \pm 2.3$ \\
\hline \multicolumn{8}{|c|}{ Non-obese, non-Insulin } \\
\hline \multicolumn{8}{|c|}{ Dependent Diabetic Patients: } \\
\hline Range & $(200-460)$ & $(80-140)$ & $(60-145)$ & $(65-180)$ & $(75-180)$ & $(45-150)$ & $(81.9-93)$ \\
\hline Mean \pm S.E. & $335.3 \pm 20.6$ & $106.7 \pm 5.2$ & $105 \pm 6.4$ & $102 \pm 8.5$ & $115.7 \pm 9.1$ & $89.3 \pm 7.7$ & $86.41 \pm 0.87$ \\
\hline $\mathrm{P}$ value $=$ & 0.05 & N.S. & N.S. & N.S. & N.S. & 0.05 & 0.001 \\
\hline
\end{tabular}

$P$ value: $t$-test for distribution differences between two samples means.

N.S.: Non-significant.

$p=0.05$ : Significant.

$p=0.001$ : Very highly significant.

partial thromboplastin, thrombin time, clotting factors II, VII, IX \& $\mathrm{X}$ activities, protein $\mathrm{C}$, fibrinogen using a kit supplied by Behringwerke AG, Marburg, Germany. ADP-induced platelet aggregation by Born [4], $a_{2}$ - antiplasmin, Plasminogen \& Plasminogen activator inhibitor (PAI) were determined kinetically using the kit supplied by behringwereke AG, Marburg Germany. Fibrin degradation products (FDPs) were assayed by the use of latex particles coated with monoclonal antibodies to FDP according to the method of Mirshahi et al. [19].

\subsection{Statistical analysis}

The statistical computation in this study were performed using the IBM-Personal Computer XT, statistical package SPSS for windows version 10.05.

\section{Results}

From the results given in Table 1, values of prothrombin time, partial thromboplastin and thrombin time in insulin dependent diabetic patients showed statistically insignificant differences when compared to the control group.

The mean normal value of plasminogen, $a_{2}$ - antiplasmin, and plasminogen activator inhibitor were found to be $106 \pm 3.75 \%, 103.1 \pm 4.5 \%$ and $1.853 \pm 0.192 \%$ respectively. The insulin dependent diabetic patients exhibited a non-significant change in plasminogen, plasminogen activator inhibitor and a very highly significant elevation in $a_{2}$ - antiplasmin $(p=0.001)$ compared to its healthy control group (Table 1). Also, fibrin degradation products in insulin dependent diabetic patients were found to be negative.

Significantly elevated mean plasma fibrinogen was observed in insulin dependent diabetic patients (339.0 
$\pm 19.9 \mathrm{mg} / \mathrm{dl}$.) as compared to the healthy control $(279.8 \pm 11.3 \mathrm{mg} / \mathrm{dl}).(p=0.05)$ (Table 2$)$.

From the results represented in Table 2, we observed non-significant differences in coagulation factors (II, VII, IX and X) and ADP-induced platelet aggregation $(\%)$ in insulin dependent diabetic patients compared with their healthy control.

The mean values of anticoagulant protein $\mathrm{C}$ was significantly decreased in insulin dependent diabetic patients $(68.3 \pm 8.2 \%)$ as compared to that of their healthy control $(121.6 \pm 6.3 \%)(p=0.001)$ (Table 2).

Form the results represented in Table 3, we observed insignificant differences in prothrombin time, partial thromboplastin time and thrombin time in non-obese, non-insulin dependent diabetic patients compared to that of the control group.

Table 3 showed that the mean normal levels of $a_{2}$ antiplasmin and plasminogen activator inhibitor were found to be $102.9 \pm 4.3 \%$ and $2.04 \pm 0.188 \%$ respectively. The non-obese, non-insulin dependent diabetic patients showed a highly significant increase in plasminogen activator inhibitor $(p=0.01,=0.001$ respectively) compared to its control group.

The mean value of plasminogen in non-obese, non-insulin dependent diabetic patients (117.247 \pm $3.954 \%$ ) showed a statistically non-insulin difference as compared to their healthy control group (Table 3). Also fibrin degradation products in non-obese, non-insulin dependent diabetic patients was found to be negative.

Significantly elevated mean plasma fibrinogen was observed in non-obese, non-insulin dependent diabetic patients $(335.3 \pm 10.5 \mathrm{mg} / \mathrm{dl}$. $)$ as compared to the healthy control $(269.7 \pm 10.5 \mathrm{mg} / \mathrm{dl})(p=0.05)$ (Table 4).

Our results listed in Table 4 revealed anon-significant changes in coagulation factors I, VII, IX, and X in nonobese, non-insulin dependent diabetic patients compared with their healthy control.

The mean values of anticoagulant protein $\mathrm{C}$ was significantly decreased in non-obese, non-insulin dependent diabetic patients $(89.3 \pm 7.71 \%)$ as compared to that of their healthy control $(113.6 \pm 4.4 \%)(p=0.05)$ (Table 4).

The mean ADP- induced platelet aggregation (\%) in non-obese healthy control was $65.3 \pm 2.3 \%$. The mean ADP-induced platelet aggregation in non-obese, noninsulin dependent diabetic patients $(86.41 \pm 0.87 \%)$ was statistically higher than that of the control group $(p=0.001)$ (Table 4).

Table 5 showed insignificant differences in prothrombin time, partial thromboplastin time and throm- bin time in obese non-insulin dependent diabetic patients compared to that of obese control group.

Table 5 showed that then mean normal levels of $a_{2^{-}}$ antiplasmin and plasminogen activator inhibitor were found to be $108.0 \pm 4.8 \%$ and $1.56 \pm 0.18 \%$ respectively. The obese, non-insulin dependent diabetic patients showed a highly significant increase in $a_{2^{-}}$antiplasmin and very highly significant increase in plasminogen activator inhibitor $(p=0.01,=0.001$ respectively) compared to its control obese group.

The plasminogen activator inhibitor level showed good specificity in both non-obese and obese noninsulin dependent diabetic patients at decision level above $3.4 \mathrm{IU} / \mathrm{ml}$ and $2.8 \mathrm{IU} / \mathrm{ml}$ respectively, it was also very sensitive in distinguishing obese non-insulin dependent diabetics from their healthy control (Table 7).

The mean values of plasminogen in obese, noninsulin dependent diabetic patients $(112.133 \pm 3.957 \%)$ showed statistically non-significant difference as compared to their obese control (Table 5). Also, fibrin degradation products in obese, non-insulin dependent diabetic patients was found to be negative.

From the results represented in Table 6, we observed insignificant differences in coagulation factors II, VII, IX and $\mathrm{X}$ in obese, non-insulin dependent diabetic patients compared with obese control group.

The mean normal values of fibrinogen and anticoagulant protein $\mathrm{C}$ were found to be $279.5 \pm 11.9 \mathrm{mg} / \mathrm{dl}$ and $115.9 \pm 4.8 \%$ respectively. The obese non-insulin dependent diabetic patients exhibited a significant increase in fibrinogen $(345.7 \pm 28.6 \mathrm{mg} / \mathrm{dl})$ compared to obese control $(p=0.05)$ and a significant decrease in protein $\mathrm{C}$ was observed $(88.9 \pm 8.7 \%)$ compared to obese control ( $p=0.05$ ) (Table 6).

Our data in Table 6 have shown a very highly significant increase in ADP- induced platelet aggregation \% (mean \pm S.E., $96.49 \pm 1.95 \%$ ) as compared with obese control (mean \pm S.E., $66.73 \pm 2.33 \%)(p=0.001)$.

\section{Discussion}

Diabetic patients are considered to beat increased risk of thromboembolic disease, but it seems that, this assumption is not entirely true. These patients are not particularly prone to the classic presentations of thrombophilic diathesis, such as deep vein thrombosis or pulmonary embolism, but are at high risk for atherosclerosis and its vaso-occlusive complications [1]. Multiple occlusions also occur in the small vessels of the retina. Peripheral nerves and other tissues. Diabetes mellitus 
Table 5

Haemostasis parameters of obese, non-insulin dependent diabetic patients compared to obese healthy control group

\begin{tabular}{|c|c|c|c|c|c|c|c|}
\hline Groups & $\begin{array}{c}\text { Prothrombin } \\
\text { Time (PT) } \\
(\text { secs })\end{array}$ & $\begin{array}{c}\text { Partial } \\
\text { Thromboplastin } \\
\text { Time (PTT) (Secs) }\end{array}$ & $\begin{array}{c}\text { Thrombin } \\
\text { Time (TT) } \\
(\text { Secs) }\end{array}$ & $\begin{array}{c}\text { Plasminogen } \\
(\%)\end{array}$ & $\begin{array}{c}a_{2^{-}} \\
\text {antiplasmin } \\
(\%)\end{array}$ & $\begin{array}{c}\text { Plasminogen } \\
\text { activator inhibitor } \\
(\mathrm{IU} / \mathrm{ml})\end{array}$ & $\begin{array}{c}\text { Fibrin } \\
\text { degradation } \\
\text { products (FDPs) }\end{array}$ \\
\hline \multicolumn{8}{|l|}{ Obese control: } \\
\hline Range & $(11.0-14.9)$ & $(31.8-38.7)$ & $(13.2-17.8)$ & $(88.0-140.0)$ & $(83.0-138.0)$ & $(0.4-2.6)$ & Negative \\
\hline Mean \pm S.E. & $12.86 \pm 0.35$ & $35.47 \pm 0.53$ & $15.17 \pm 0.32$ & $112.13 \pm 3.96$ & $108.0 \pm 4.8$ & $1.56 \pm 0.12$ & \\
\hline \multicolumn{8}{|c|}{ Obese, non-Insulin } \\
\hline \multicolumn{8}{|c|}{ Dependent Diabetic } \\
\hline \multicolumn{8}{|c|}{ Patients: } \\
\hline Range & $(10.9-13.6)$ & $(32.0-43.0)$ & $(10.6-18.3)$ & $(90.57-150.0)$ & $(100-190)$ & $(2.39-8.29)$ & Negative \\
\hline Mean \pm S.E. & $12.22 \pm 0.21$ & $36.77 \pm 0.88$ & $15.77 \pm 0.58$ & $122.68 \pm 5.17$ & $134.3 \pm 5.6$ & $5.32 \pm 0.47$ & \\
\hline $\mathrm{P}$ value $=$ & N.S. & N.S. & N.S. & N.S. & 0.01 & 0.001 & \\
\hline
\end{tabular}

$P$ value: t-test for distribution differences between two samples means.

N.S.: Non-significant.

$p=0.01$ : highly significant.

$p=0.001$ : Very highly significant.

Table 6

Fibrinogen, factors II, VII, IX \& X , protein C and ADP-induced platelet aggregation levels in obese, non- insulin dependent diabetic patients compared to obese control group

\begin{tabular}{|c|c|c|c|c|c|c|c|}
\hline Groups & $\begin{array}{l}\text { Fibrinogen } \\
(\mathrm{mg} / \mathrm{dl})\end{array}$ & $\begin{array}{l}\text { Factor } \\
\text { II }(\%)\end{array}$ & $\begin{array}{c}\text { Factor } \\
\text { VII }(\%)\end{array}$ & $\begin{array}{l}\text { Factor } \\
\text { IX }(\%)\end{array}$ & $\begin{array}{l}\text { Factor } \\
X(\%)\end{array}$ & $\begin{array}{l}\text { Protein } \\
\mathrm{C}(\%)\end{array}$ & $\begin{array}{c}\text { ADP-induced } \\
\text { platelet } \\
\text { aggregation (\%) }\end{array}$ \\
\hline \multicolumn{8}{|l|}{ Obese control: } \\
\hline Range & $(215-380)$ & $(75-162)$ & $(85-153)$ & $(79-165)$ & $(75-155)$ & $(75-142)$ & $(55-68)$ \\
\hline Mean \pm S.E. & $279.5 \pm 11.9$ & $114.3 \pm 7.2$ & $108.9 \pm 5.2$ & $112.5 \pm 6.4$ & $115.6 \pm 5.7$ & $115.9 \pm 4.8$ & $66.73 \pm 2.33$ \\
\hline \multicolumn{8}{|c|}{ Obese, non-Insulin } \\
\hline \multicolumn{8}{|c|}{ Dependent Diabetic Patients: } \\
\hline Range & $(200-550)$ & $(75-170)$ & $(80-165)$ & (70-200) & $(75-140)$ & $(33-141)$ & $(88-110)$ \\
\hline Mean \pm S.E. & $345.7 \pm 28.6$ & $109.7 \pm 6.7$ & $115 \pm 6.6$ & $120.3 \pm 9.7$ & $102.3 \pm 5.5$ & $88.9 \pm 8.7$ & $96.49 \pm 1.95$ \\
\hline $\mathrm{P}$ value $=$ & 0.05 & N.S. & N.S. & N.S. & N.S. & 0.05 & 0.001 \\
\hline
\end{tabular}

$P$ value: $t$-test for distribution differences between two samples means.

N.S.: Non-significant.

$p=0.05$ : Significant.

$p=0.001$ : Very highly significant.

therefore appears to damage the vessels making them more susceptible to occlusion [23].

The coagulation abnormalities observed in diabetic patients seem to be caused by the hyperglycemia, which also contributes the distinguishing feature of this disease [6]. Fibrinolytic activity has been reported to be normal, elevated or low in diabetic patients [15]. Alterations in factors such as fibrinogen concentration and turnover, fibronectin, and platelet adhesiveness and aggregation are found in non-insulin dependent diabetic patients and can leadto excess accumulation of fibrin and platelet on vascular walls [14].

The results assay of coagulation factors II, VII and $\mathrm{X}$ in diabetic patient groups were not statistically different from that of the healthy control groups. This finding is in agreement with the studies of Ibbotson et al. [13] who suggested that any differences in generation of thrombin activity in plasma of diabetic patients compared to normal individuals are likely to be insignificant and the blood coagulation is not enhanced in diabetic patients compared with control subjects.

However, there was significant difference in factor VII level being higher in obese, non-insulin dependent diabetic patients compared to insulin dependent diabetic patients. This may accuse obesity as a risk factor in the pathogenesis of thrombosis. These results were similar to obese of Primrose et al. [24] who noticed that factor VII levels found to be of higher levels in obese patients compared to control group.

Obesity is associated with hyperinsulinemia and hyperlipidemia as well as enhancing haemostasis and decreasing fibrinolytic function [24].

Regarding fibrinogen level, high significant level was demonstrated in the three groups of diabetes studied compared to their controls but the difference between each one of the three groups and the other was insignificant. 
Table 7

Diagnostic performance of $a_{2}$ - antiplasmin and plasminogen activator inhibitor in different diabetic groups studied

\begin{tabular}{|c|c|c|}
\hline Groups & $a_{2}-\operatorname{antiplasmin}(\%)$ & Plasminogen activator inhibitor (PAI) (IU/ml) \\
\hline \multicolumn{3}{|c|}{$\begin{array}{l}\text { Insulin dependent diabetic } \\
\text { patients Vs Healthy control }\end{array}$} \\
\hline Decision Level & $>147$ & Non-Significant \\
\hline Sensitivity (\%) & 100 & $(p>0.05)$ \\
\hline Specificity (\%) & 65 & No separation \\
\hline *PPV $(\%)$ & 47 & between the two groups. \\
\hline$* *$ NPV $(\%)$ & 100 & \\
\hline efficiency $(\%)$ & 73 & \\
\hline \multicolumn{3}{|c|}{$\begin{array}{l}\text { Insulin dependent diabetic } \\
\text { patients Vs Healthy control }\end{array}$} \\
\hline Decision Level & $>130$ & $>3.4$ \\
\hline Sensitivity $(\%)$ & 100 & 100 \\
\hline Specificity (\%) & 65 & 71 \\
\hline *PPV $(\%)$ & 47 & 60 \\
\hline$* * \operatorname{NPV}(\%)$ & 100 & 100 \\
\hline efficiency $(\%)$ & 73 & 80 \\
\hline \multicolumn{3}{|c|}{$\begin{array}{l}\text { Insulin dependent diabetic } \\
\text { patients Vs Healthy control }\end{array}$} \\
\hline Decision Level & $>140$ & $>2.8$ \\
\hline Sensitivity $(\%)$ & 100 & 100 \\
\hline Specificity (\%) & 60 & 71 \\
\hline *PPV (\%) & 33 & 100 \\
\hline${ }^{* *}$ NPV $(\%)$ & 100 & 100 \\
\hline efficiency $(\%)$ & 67 & 97 \\
\hline
\end{tabular}

Sensitivity (\%): Percentage of people with the disease who have a positive test.

Specificity $(\%)$ : Percentage of people without the disease who have a negative test.

*PPV (\%): Positive Predictive Values.

${ }^{* *}$ NPV $(\%)$ : Negative Predictive Values.

Increased plasma fibrinogen may contribute to a hypercoagulable state in non-insulin dependent diabetes mellitus [10]. Fibrinogen may induce thrombus formation by affecting platelets and erythrocytes to aggregation and by promoting increased blood viscosity [20]. Plasma fibrinogen is often elevated in diabetes which has been identified as a major vascular risk factor [12].

Also, fibrinogen, the immediate precursor of fibrin, is frequently elevated in patients with non-insulin dependent diabetes mellitus and this elevation is associated with poor glycemic control [18]. It has been previously shown that increased fibrinogen synthesis and turnover in diabetes are related to insulin deficiency and can be corrected by insulin administration [8].

Protein $\mathrm{C}$ is one of the most important antithrombotic components. After activation by thrombinthrombomodulin complex on the endothelial cells, activated protein C ( APC) inactivates factor VIIIa and $\mathrm{Va}$ and hence, inhibits thrombin formation.

APC was demonstrated to show profibrinolytic activity by inactivating plasminogen activator inhibitor. Since severe thrombosis was observed in patients with protein $\mathrm{C}$ deficiency. Protein $\mathrm{C}$ might play a critical role in antithrombotic process. Protein $\mathrm{C}$ might be consumed by developing the hypercoagulable state [22].
Compared with carefully matched control subjects, insulin dependent and non-insulin dependent diabetic patients showed significantly decreased level of protein $\mathrm{C}$ in plasma. This decrease may be caused by either a reduced synthesis of protein $\mathrm{C}$ in the liver or by increased clearance from the blood plasma. This decrease is an indicator of an abnormal, probably hypercoagulable, haemostatic situation in diabetic patients [26].

Our results showed no significant difference in platelet aggregation in insulin dependent diabetic patients in comparison to their control group. These results are in accordance with the findings of others who reported normal platelet aggregation in non-insulin complicated cases of type I diabetes [2,11].

Plasma $a_{2}$ - antiplasmin was significantly highly in the three groups of diabetic patients studied compared to that of their control groups. However, no significant difference was found between any one group and the other.

Cucuionu et al. [7] demonstrated that fibrinolysis was delayed by increase in the concentration of fibrinogen, plasminogen activator inhibitors, $a_{2}$ - antiplasmin and factor XIII (in he presence of $a_{2}$ - antiplasmin). Thrombin induced release of PAI from platelets also contributed to retard clot lysis [9]. 
Wun and Copuauo [29] also showed that in the presence of fibrin a certain amount of t-PA may dissociate from its complex with plasminogen activator inhibitor. The released activator will then act on the clot, particularly in low activity of factor XIII and $a_{2}$ - antiplasmin and more susceptible to fibrinolysis.

Regarding plasminogen activator inhibitor, our results indicated that non-insulin dependent diabetic patients (non-obese and obese) exhibited a very highly significant increase its level (Tables 3 and 5). Whereas a non-significant difference was found in insulin dependent diabetic patients as compared to their healthy control groups.

This parameter which has also proved to have high diagnostic efficiency may play a cardinal role in the follow-up of diabetic patients and could be considered as good prognostic factor in follow-up of patients to detect early development of a prothrombotic state particularly in non-insulin dependent diabetics.

The above findings were consistent with Viceri et al. [27] who reported normal tissue plasminogen activator and plasminogen activator inhibitor activity in plasma from patients with type I diabetes mellitus.

The altered levels of PAI-1 in patients with diabetes may result from genetic polymorphisms influencing PAI-1 gene expression. Theoretically such polymorphisms could exist at or near the PAI-1 gene or at some distant gene which codes for a factor that controls PAI-1 gene expression [21].

Fibrin/fibrinogen degradation products in all diabetic patients studied were found to be negative reflecting insignificant intravascular coagulapthy. Jones et al. [16] were unable to demonstrate any fibrin degradation products consistently in any of the diabetic patients.

From these findings we may conclude that high levels of plasma fibrinogen, $a_{2}$ - antiplasmin with low plasma protein $\mathrm{C}$ activity could to a prothrombotic tendency in insulin dependent diabetic patients. Moreover, in non-insulin dependent diabetic patients, the above mentioned parameters together with high levels of ADPinduced platelet aggregation and plasminogen activator inhibitor may increase the risk of thrombotic complications.It was also demonstrated that plasminogen activator inhibitor, serum cholesterol and triacylglycerol were higher in obese non-insulin dependent diabetic patients. From these observations we may suggest that obesity can be considered as an additional risk factor for development of thrombosis in diabetic patients.

\section{References}

[1] C. Abraira, M. Emanuele, J. Colwell, W. Henderson, J. Comstock, S. Levin, F. Nuttal and C. Sawin, Clycaemic control and complications in type II diabetes: Design of feasibility trial, Diabetes Care 15 (1992), 1560-1571.

[2] P. Alessananadrini, J. McRac, S. Ferman and A. Fitzgerald, Thromboxan biosynthesis and platelet function in type I diabetes mellitus, N. Eng. J. Med. 319 (1988), 208-212.

[3] G.J. Biesseles, A.C. Kappelle, B. Bravenboer, D.W. Erkelens and W.H. Gispen, Cerebral function in diabetes mellitus, $\mathrm{Di}$ abetologia 37 (1994), 643-650.

[4] G.V.R. Born, Aggregation of blood platelet by adinosine diphosphate and its reversal, Nature 124 (1962), 927.

[5] M.E. Carr, Diabetes mellitus: A hypercoagulable state, J. Diabet Compl. 15 (2001), 44-54.

[6] A. Ceriello, A. Quatraro and E. Marchi, Istituto di scienze mediche, Facolta di Medicina, Universita di Udine, P. to Sanata Maria Della Misericordia, 1-33100 Udine ITA, Diabete Metabol 1912 (1993), 225-229 - Summ. In Engl.

[7] M. Cucuianu, O. Knauer and S. AND roman, $a_{2}$ - antiplasmin, plasminogen activator inhibitor (PAI) and dilute blood clot lysis time in selected disease states, Thrombosis and Haemostasis 66(5) (1991), 586-591.

[8] P. De Feo, M.G. Caisano and M.W. Haymond, Differential effects of insulin deficiency on albumin and fibrinogen synthesis in humans, J. Clin. Ivest. 88 (1991), 833-840.

[9] N.J. DeFouw, Y.P. De Jong, P. Hyerkate and B.M. Bertina, The influence of thrombin and platelets on fibrin colt lysis rates in vitro: astudyusing clot lysis system consisting of purified human proteins, Fibrinolysis 2 (1988), 35-44.

[10] J.H. Fuller, H. Keen and R.J. Jarrett, haemostatic variables associated with diabetes and its complications, British Medical $J$ ii (1979), 964-966.

[11] C.H. Gisinger and G. Scherthaner, Increased platelet molondehyde but normal platelet sensitivity to adenosine diphosphate and prostacycline in well controlled type I diabetes without vascular complication, Diabetes R 3 (1986) 401-405.

[12] W.G. Hornsby, K.A. Boggess, T.J. Lyons, W.H. Barnwell, J. Lazarchick and J.A.B. Colwell, Haemostatic alterations with exercise conditioning in NIDD, Diabetes Care 13 (1990), 8792.

[13] S.H. Ibbotson, D. Walmsley, J.A. Davies and P.J. grant, Generation of thrombin activity in relation to factor VIII: C concentrations and vascular complications in type 1 (insulin dependent) diabetes mellitus, Diabetologia 35 (1992), 863-867.

[14] T. Inoguchi, F. Umeda, J. Watanabe, T. Wasada and H. Ibavashi, Plasma fibronetin and platelet aggregation in diabetes mellitus, Diabetes Res. Clin. Pract. 2 (1986), 69-73.

[15] I. Juhan-Vague, C. Roul, M.C. Alessi, M. Heim and P. Vague, Increased plasminogen activator inhibitor activity in noninsulin dependent diabetic patients. Relationship with plasma insulin, Thromb. Haemostas. 61 (1989), 370-373.

[16] R.L. Jones and C.M. Peterson, Reduced fibrinogen survival in diabetes mellitus, a reversible phenomenon, J. Clin. Invest. 63 (1979), 485.

[17] H.C. Kwaan, Changes in blood coagulation, platelet function and plasminogen-plasmin system in diabetes, Diabetes $4(2)$ (1992), 32-35.

[18] W.B. Kannel, R.B. D’Agostino, R.B. Wilson, A.J. Belanger and D.R. Gagnon, Diabetes, fibrinogen and risk of cardiovascular disease: the Framingham experience, Am. Heart J. 120 (1990), 672-676. 
[19] M. Mirshahi, J. Soria, C. Soria, J.Y. Perrot and C. Boucheix, A latex immunoassay of fibrin/fibrinogen products in plasma using a monoclonalantibody, Thromb. Res. 44 (1986), 715728.

[20] E.W. Merrill, Rheology of blood, Physiol. Rev. 49 (1969), 863-887.

[21] M.W. Mansfield, M.H. Stickland, A.M. Carter and P.J. Grant, Polymorphisms of the plasminogen activator inhibitor-1 gene in type 1 and type 2 diabetes and in patients with diabetes retinopathy, Thromb. Haemost. 71 (1994), 731-736.

[22] K. Okajima, S. Koga, M. Kaji, M. Inoue, T. Nakagaki, A. Funatsu, H. Okabe, K. Takatsuki and N. Aoki, Effects of protein $\mathrm{C}$ and activated protein $\mathrm{C}$ on coagulation and fibrinolysis in normal human subjects, Thrombosis and Haemostasis 63(1) (1990), 48-53.

[23] M. Porta, M. La Selva, E. Beltramo, P. Passera and G.M. Molinatti, Hemostasis and thrombosis in relation to endothelial dysfunction in diabetes mellitus, Medicographia 16(1) (1994), 28-31.

[24] J.N. Primrose, J.A. Davies, C.R.M. Prentice, R. Hughes and D. Johnston, Reduction in factor VII, fibrinogen and plasminogen activator-1 activity after surgical treatment of morbid obesity, Thrombosis and Haemostasis 68(4) (1992), 396-399.

[25] T. Vukovich, S. Proidl, P. Knoble, H. Teufelsbauer, C. Schnack and G. Schernthaner, The effect of insulin treatment on the balance between tissue plasminogen activator and plasminogen activator inhibitor- 1 in type 2 diabetic patients, Thromb Haemst 68 (1992), 253-256.

[26] T.C. Vukovich and G. Schernthaner, Decreasedprotein C levels in patients with insulin-dependent type 1 diabetes mellitus, Diabetes 35 (1986), 617-619.

[27] A.M. Vicari, S. Vigano D'Angelo, S. Testa, G. Comi, G. Galardi, E. Orsi and A. D'Angelo, Normal tissue plasminogen activator and plasminogen activator inhibitor activity in plasma from patients with type 1 diabetes mellitus, Horm. Metab. Res. 14 (1992), 516-529.

[28] WHO Study Group on Diabetes Mellitus. Diabetes mellitus: report of a WHO study group. Geneva: World Health Organization technical report series no. 717, 1985.

[29] T.G. Wun and A. Capuano, Inhibition and regulation of fibrinolysis in human plasma at the plasminogen activator level, Blood 69 (1987), 1354-1382. 


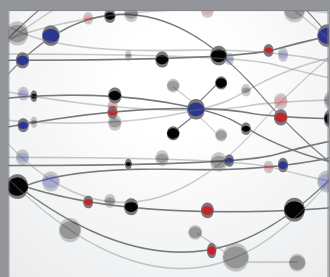

The Scientific World Journal
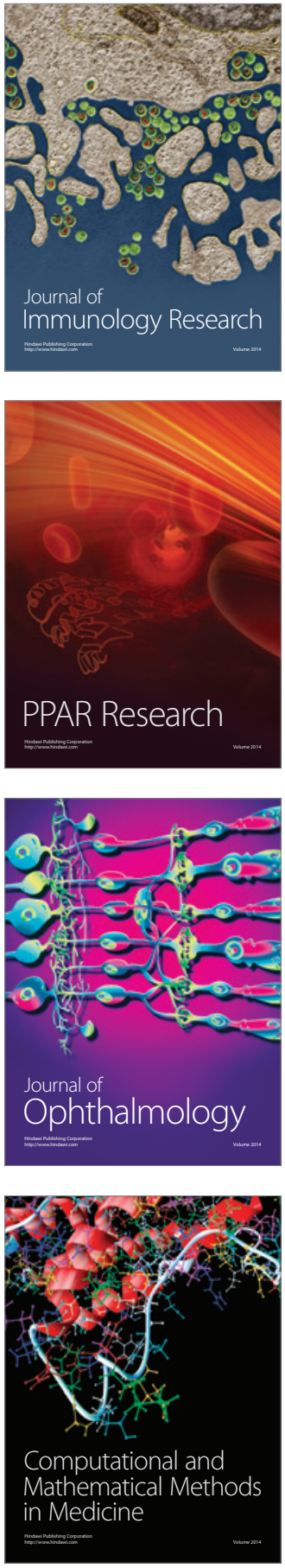

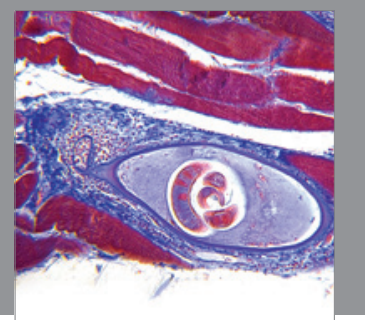

Gastroenterology

Research and Practice
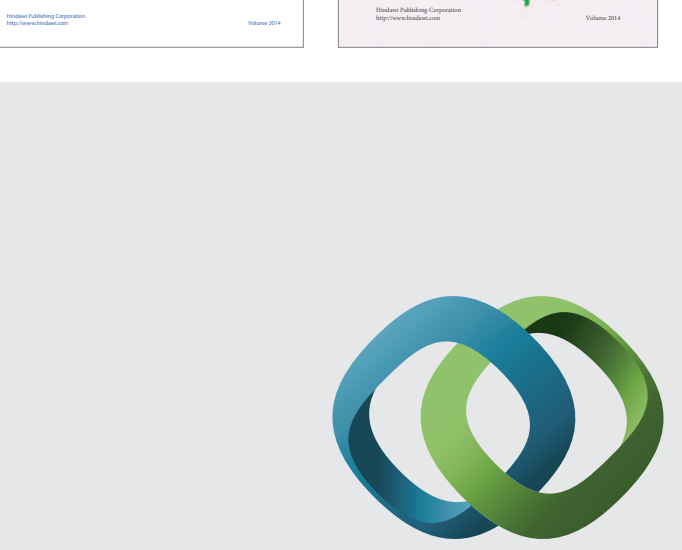

\section{Hindawi}

Submit your manuscripts at

http://www.hindawi.com
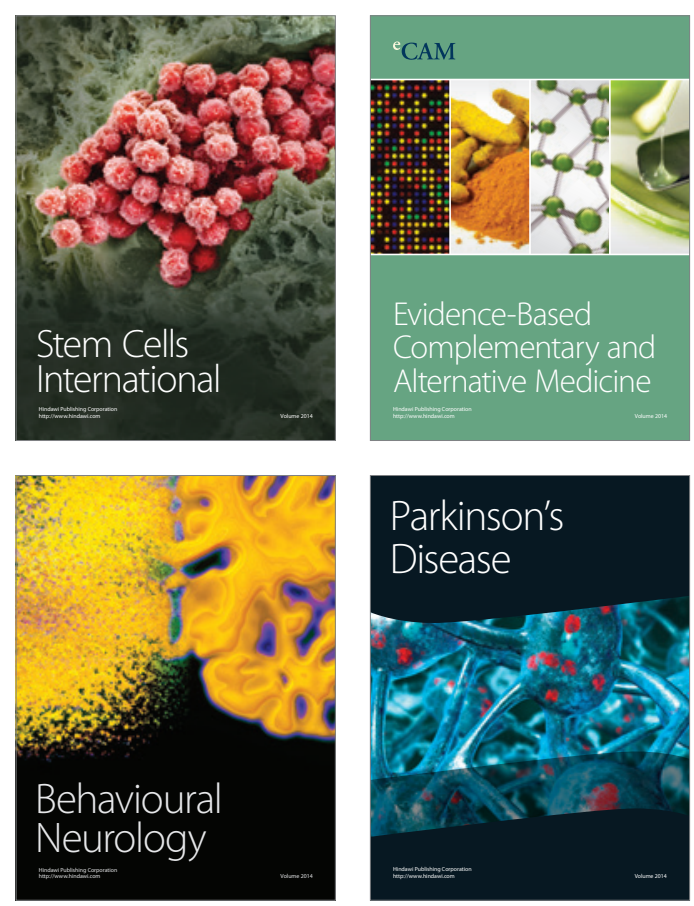

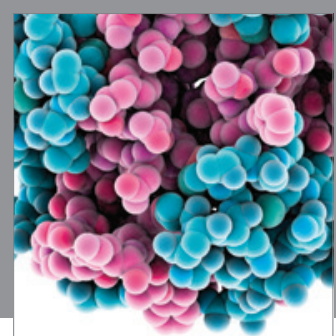

Journal of
Diabetes Research

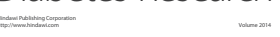

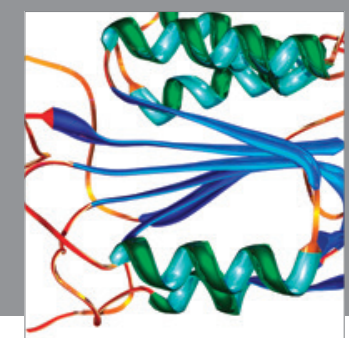

Disease Markers
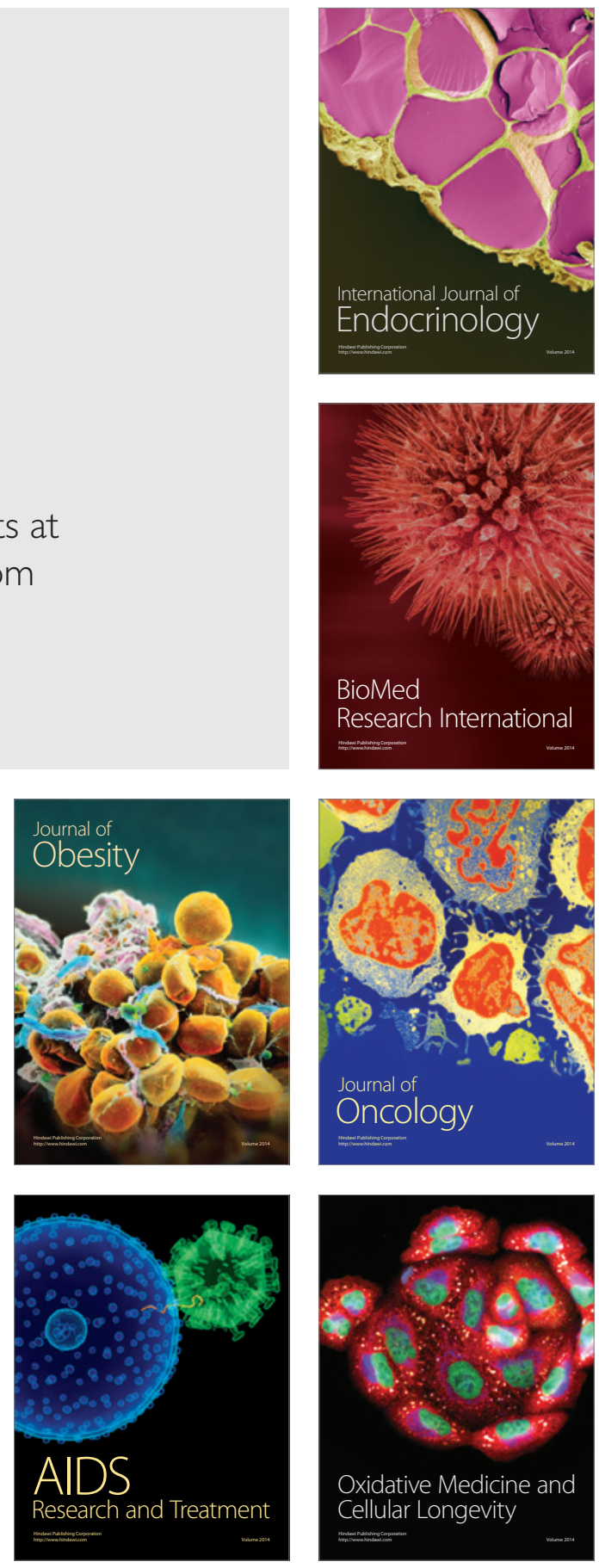